\title{
The Constitutionality of the 1942 Price Control Act.
}

\author{
Joseph W.Aidlin*
}

DURING the last decade the manifold and difficult social and economic problems with which our nation has had to cope have necessitated the opening of vistas of legislative activity hitherto closed to legislative bodies. Constitutional concepts have been broadened, although not without difficulty, so that today the federal government exercises greater powers and exerts a greater influence over the activities of all persons than at any time in our history.

Conditions arising out of the conduct of the war in which we are $\cdot$ engaged have required bold and sweeping measures, and not the least of these is the Emergency Price Control Act of $1942^{1}$-an act, according to its purpose as declared by Congress, ". . . in the interest of the national defense and security and necessary to the effective prosecution of the present war...." To effectuate this major purpose the Act is intended "... to stabilize prices and to prevent speculative, unwarranted, and abnormal increases in prices and rents; to eliminate and prevent profiteering, hoarding, manipulation, speculation, and other disruptive practices resulting from abnormal market conditions or scarcities ... to assure that defense appropriations are not dissipated by excessive prices . . . to assist in securing adequate production of commodities and facilities; to prevent a post emergency collapse of values; to stabilize agricultural prices ..." and to effect other stated purposes. ${ }^{2}$

The Act provides that if in the opinion of the Price Administrator prices rise or threaten to rise to an extent inconsistent with the purposes of the Act, he may by regulation establish maximum prices which are in his judgment generally fair and equitable and will effectuate the purposes of the Act. ${ }^{3}$ The Act also declares it unlawful, "... regardless of any contract, agreement, lease, or other obligation heretofore or hereafter entered into ...", for any person

*Member of the Los Angeles Bar; A.B., University of California at Los Angeles, 1930; LL.B., University of California, 1933. Member Executive Board, Los Angeles Chapter, National Lawyers Guild.

\footnotetext{
1 Pub. L. No. 421, 77th Cong. 2d Sess. (Jan. 30, 1942).

2 Ibid. \$1(a).

3 Ibid. \$2(a).
} 
to sell or deliver or buy or receive any commodity or to demand or receive any rent for any defense-area housing accommodations, or to do or omit to do any act in violation of any regulation, order or price schedule, or to offer, solicit, attempt or agree to do any of the foregoing. ${ }^{4}$

Pursuant to the authority granted to him under the Act the Price Administrator did, on April 28, 1942, issue the General Maximum Price Regulation ${ }^{5}$ which established maximum prices for most commodities generally dealt in and many services commonly rendered.

The Emergency Price Control Act and the regulations and orders promulgated pursuant to its provisions by the Price Administrator raise numerous complex and fundamental questions of law. It is not the intention of the writer to consider here all of these questions," but rather to limit the scope of this article to a brief consideration of the legal effect and constitutional validity of the Act and regulations thereunder in so far as they affect existing contractual relations. Would a regulation fixing a maximum price violate any constitutional guarantees of parties to an existing contract calling for the purchase and sale of a commodity or the rendering of a service at a price higher than the maximum established? Does a lessor under an existing lease have any constitutional protection against an order setting maximum rents in a defense-area if such rents are lower than that called for under the lease? May a manufacturer who is unable to produce profitably at the maximum price fixed for his commodity and is, therefore, unable to meet his fixed obligations claim that he has been deprived of "due process" in the event he is forced to close his business? What are the rights and liabilities of parties to an existing contract affected by a regulation of the Price Administrator? The lawyer, today, is called upon to answer many such questions, and in making proper answer he renders valuable service not only to his client but to the community at large.

Upon a careful reading of the Act one is impressed with the skill

4 Ibid. $\$ 4(a)$.

57 FED. REg. (April 30, 1942) 3153, tit. 32, c. XI, pt. 1499, $\$ \$ 1499.1-1499.25$ inc. Shown as part 1500 in the original regulation issued April 28, 1942.

6 For a consideration of the question of delegation of legislative powers see the following cases: Wayman v. Southard (1825) 23 U. S. (10 Wheat.) 1; United States v. Grimaud (1910) 220 U. S. 506; Panama Refining Co. v. Ryan (1935) 293 U. S. 388; Schechter Corp. v. United States (1935) 295 U. S. 495 ; Carter v. Carter Coal Co. (1936) 298 U.S. 238; Opp Cotton Mills v. Administrator (1940) 312 U.S. 126. A study of the cases indicates that the Emergency Price Control Act has properly complied with the rules laid down for a valid delegation of power by Congress. 
and thoroughness evident in its preparation. Provision is made for most contingencies, among them being the provision protecting persons against liability for damages because of compliance with the Act. Section 205(d) of the Act provides that "No person shall be held liable for damages or penalties in any Federal, State, or Territorial court, on any grounds for or in respect of anything done or omitted to be done in good faith pursuant to any provision of this Act or any regulation, order, price schedule, requirement, or agreement thereunder ... notwithstanding that subsequently such provision, regulation, order, price schedule, requirement, or agreement may be modified, rescinded, or determined to be invalid."

A party to a contract, the terms of which are affected by a regulation, order or price schedule made under the Act is prohibited from performing under the terms of such contract in violation of such regulation. ${ }^{7}$ The contract, in so far as it conflicts with such regulation, becomes illegal and void and refusal to perform does not subject the contracting party to liability for breach of contract. ${ }^{6}$ This is true even if. such regulation were subsequently declared invalid. ${ }^{\circ}$

Apart from the practical every day problems occasioned by the various regulations and price schedules, the larger question of the constitutionality of the Emergency Price Control Act is undoubtedly of greater importance, for the determination of whether or not legislation impairing the obligation of contract and providing by its terms for the regulation of practically every field of economic activity, intrastate as well as interstate, is a proper exercise of congressional power may indicate the limits, if any, to regulation and control by the federal government during and after the war, and may resolve doubts now current as to the constitutionality of many present day activities of the federal government.

Although the Constitution specifically forbids any state from passing any law impairing the obligation of contract, ${ }^{10}$ there is no such specific limitation imposed upon the federal government. Congress is not prohibited from passing a law which impairs the obligation of contract if such law is incidental to the exercise by Congress

$7 \S 4(a)$.

8 Louisville \& Nashville R. R. v. Mottley (1911) 219 U. S. 467. See $\$ 4$ (d) of the Act.

9 \$205(d) of the Act. Louisville \& Nashville R. R. v. Mottley, supra note 8; Cooley v. County of Calaveras (1898) $121 \mathrm{Cal}$. 482, 53 Pac. 1075; Wingerter v. San Francisco (1901) 134 Cal. 547, 66 Pac. 730; Campbell v. Rainey (1932) 127 Cal. App. 747, 16 P. (2d) 310 .

10 U. S. Const., Art. I, §10. 
of its constitutional powers, ${ }^{11}$ and does not violate the "due process" clause of the Fifth Amendment. ${ }^{12}$ In the words of Chief Justice Hughes, "Contracts, however express, cannot fetter the constitutional authority of the Congress. Contracts may create rights of property, but when contracts deal with a subject matter which lies within the control of the Congress, they have a congenital infirmity. Parties cannot remove their transactions from the reach of dominant constitutional power by making contracts about them." ${ }^{13}$

It is apparent that the constitutionality of the Emergency Price Control Act and the regulations issued thereunder must depend upon the existence of a paramount constitutional power residing in Congress. Those powers of Congress germane to this discussion are as follows: (a) the power to tax and spend to provide for the common defense and the general welfare of the United States, (b) the power to regulate interstate commerce, (c) the war powers of Congress, and (d) the power to make all laws which shall be necessary and proper for carrying into execution the enumerated powers. ${ }^{14}$ It is necessary, then, to consider the extent of these congressional powers in relation to the scope and purposes of the Emergency Price Control Act.

The power of Congress to regulate interstate commerce has been expanded greatly in recent years. The power is not confined to the regulation of commerce among the states and with foreign countries. It extends to those intrastate activities which so affect interstate commerce or the exercise of the power of Congress over it as to make regulation of such intrastate activities an appropriate exercise of the power of Congress to regulate interstate commerce. ${ }^{15}$

Although the power to regulate interstate commerce is a broad congressional power, there are definite limitations to that power which would preclude basing the validity of the Emergency Price

11 Louisville \& Nashville R. R. v. Mottley, supra note 8 ; Norman v. B.\&O. R. Co. (1935) 294 U.S. 240.

12 Hepburn v. Griswold (1869) 75 U. S. (8 Wall.) 603; Adkins v. Children's Hospital (1923) 261 U. S. 525; Louisville J. Bank v. Radford (1935) 295 U. S. 555; St. Joseph Stock Yards Co. v. United States (1936) 298 U. S. 38.

13 Norman v. B. \& O. R. Co., supra note 11, at 307.

14. U. S. Const., Art. I, \$8.

15 Northern Securities Co. v. United States (1904) 193 U. S. 197; Swift \& Co. v. United States (1905) 196 U. S. 375; Coronado Coal Co. v. United Mine Workers (1925) 268 U. S. 295; Labor Board v. Jones \& Laughlin (1937) 301 U. S. 1; Santa Cruz Co. v. Labor Board (1938) 303 U. S. 453 ; Currin v. Wallace (1939) 306 U. S. 1; Labor Board v. Fainblatt (1939) 306 U. S. 601 ; United States v. Darby (1940) 312 U. S. 100. 
Control Act upon the commerce clause. "... the scope of this power must be considered in the light of our dual system of government and may not be extended so as to embrace effects upon interstate commerce so indirect and remote that to embrace them, in view of our complex society, would effectually obliterate the distinction between what is national and what is local and create a completely centralized government. The question is nécessarily one of degree." 10 Upon proper occasion and by appropriate measure, a state may regulate a business in any of its aspects, including the prices to be charged for the commodities or services it sells. ${ }^{17}$ That power stems from the general police power of the state. ${ }^{18}$ What is generally referred to as the police power of the federal government, however, is not so broad or general as the police power of a state in that the federal exercise of police power rests upon the exercise of such implied powers as are necessary and proper to carry into effect the enumerated powers of Congress under the Constitution. ${ }^{19}$

It is apparent, therefore, that if the power to regulate interstate commerce is the source of the power of the federal government to regulate practically all prices for commodities and services, and to fix rents in specific localities, in order to make such price-fixing effective, strictly minastate activities must be regulated and controlled (and have been so regulated and controlled under the Act), and the commerce clause and the implied powers thereunder must stretched to such an extent as to do away completely with any limitation upon the power of Congress to regulate strictly intrastate activities.

Another delegated power of Congress is the taxing and spending power. In the exercise of this power Congress may provide for the common defense and the general welfare. ${ }^{20}$ It has not been seriously contended, and there appears to be no authority to support the prop-

16 Labor Board v. Jones \& Laughlin, supra note 15, at 37. See also Schechter Corp. v. United States, supra note 6; United States v. Butler (1936) 297 U. S. 1; Ashton v. Cameron County Dist. (1936) 298 U. S. 513.

17 Nebbia v. New York (1934) 291 U. S. 502, 539, where the Court stated, "Price control, like any other form of regulation, is unconstitutional only if arbitrary, discriminatory, or demonstrably irrelevant to the policy the legislature is free to adopt. . .." See also Munn v. Illinois (1876) 94 U. S. 113; Block v. Hirsch (1921) 256 U. S. 135; West Coast Hotel Co. v. Parrish (1937) 300 U. S. 379.

18 The Minncsota Rate Cases (1913) 230 U.S. 352 ; Nebbia v. New York, supra note 17 ; Bayside Fish Co. v. Gentry (1936) 297 U. S. 422.

19 Carter v. Carter Coal Co., supra note 6; Cincinnati Soap Co. v. United States (1937) 301 U. S. 308.

20 Steward Machine Co. v. Davis (1937) 301 U. S. 548; Helvering v. Davis (1937) 301 U. S. 619. See also United States v. Butler, sutpra note 16. 
osition that Congress has any general power; apart from its taxing and and spending power, to provide for the general welfare. The Emergency Price Control Act makes no pretense at being an exercise of the taxing and spending power of Congress. While it is the opinion of the writer that much can be said in favor of a broader interpretation of the general welfare clause so as to impart to Congress the power to legislate for the general welfare as to matters of national character and importance, without limiting the exercise of such power to the taxing and spending power, it does not appear necessary in order to sustain the validity of the Act.

It is submitted that the Act is a valid exercise of the war powers of Congress. The power granted by the Constitution to the federal government to wage war extends to all matters related to the winning of the war and to the employment of all appropriate means to wage war successfully. ${ }^{21}$ It carries with it the power to deal with all contingencies arising from the inception, progress and termination of the war. ${ }^{22}$ The war powers have been likened to the police power of a state, "... but the police power raised to the highest degree...." 23

Although the Supreme Court has held that the war powers are limited by the Fifth and Sixth Amendments, relating to personal security, due process and the taking of private property for public use, ${ }^{24}$ and although it has been held that the war powers of the federal government do not extend to regulation of activities which are considered strictly intrastate matters, ${ }^{25}$ if the war powers are comparable to and of a higher magnitude than the police power of a state, and if the power to wage war is to be at all effective, it must allow for whatever legisiation by Congress that is necessary to successfully prosecute the war and to meet the extraordinary conditions arising during the war and upon its conclusion; and such legislation

21 Highland v. Russell Car Co. (1929) 279 U. S. 253; Pappens v. United States (C. C.A. 9th, 1918) 252 Fed. 55; Grancourt v. United States (C.C.A. 9th, 1919) 258 Fed. 25; United States v. Casey (S. D. Ohio, 1917) 247 Fed. 362; Hannah \& Hogg v. Clyne (N.D. Ill. 1919) 263 Fed. 599.

22 Hamilton v. Kentucky Distilleries Co. (1919) 251 U. S. 146; Hannah \& Hogg v. Clyne, ripra note 21; Lajoie v. Milliken (1923) 242 Mass. 508, 136 N. E. 419.

23 Public Service Comm. v. New York Central R. Co. (1920) 230 N.Y. 149, 152, 129 N. E. 455, 456. See also Hamilton v. Kentucky Distilleries Co., sutpra note 22.

24 Ibid.; United States v. Cohen Grocery Co. (1921) 255 U.S. 81. But see Page v. United States (1870) 78 U.S. (11 Wall.) 268, and Chemical Foundation v. E. I. Du Pont de Nenuours \& Co. (D.Del. 1928) 29 F. (2d) 597, to the effect that statutes enacted in exercise of the war powers of Congress are not himited by the 5th and 6th Amendments.

25 United States v. Eason Oil Co. (W. D. Okla. 1934) 8 Fed. Supp. 365, declaring that the war powers do not extend to regulation of drilling of oil wells within the several states (citing nunserous authorities). 
is no less consistent with the Fifth and Sixtb Amendments than a state enactment vitally necessary for the general welfare, under the police power of the state, would be under the Fourteenth Amendment, ${ }^{28}$ and the determination of what is essential must of necessity rest with Congress. ${ }^{27}$

The war power is sovereign; it's exercise is more than an effort to preserve the health, economy or morals of a community. Its exercise involves the preservation of the nation. ${ }^{28}$ The war in which we are now engaged is a struggle for the preservation of our very existence as a democratic nation. It is a total war in which the productive and economic powers of our nation are taxed to the utmost. Every economic factor, every instrument of production, every hour worked, every item sold and service rendered, every material used bears directly upon the effectiveness of the prosecution of the war. It cannot be said that any of these activities, minute though they may seem in the larger scheme of things, are strictly local in character, strictly within the cognizance of state and not federal power, or without bearing upon the war effort. It cannot be questioned that "in the interest of national defense and security and necessary to the effective prosecution of the war" the stabilization of prices, prevention of speculation and of unwarranted and abnormal increases in prices and rents, the elimination and prevention of profiteering and hoarding, and the other stated objectives of the Emergency Price Control Act are vitally necessary.

If, in the exercise of its power to regulate interstate commerce Congress may regulate intrastate activities which have a direct bearing upon interstate commerce, then, certainly Congress may, in the exercise of its war powers, enact legislation of uniform application, such as the Emergency Price Control Act, which has as its purpose securing an economic stability which is necessary to the successful prosecution of the war. Legislation which in the discretion of Congress is necessary and proper to defend our nation cannot be said to violate the Constitution. The total character of the struggle, the extraordinary conditions created, call for legislation of the most comprehensive character. Such legislation serves the highest constitutional purpose.

26 Hamilton v. Kentucky Distilleries Co., supra note 22.

27 Ibid.; Highland v. Russell Car Co., supra note 22. See also Helvering v. Davis, supra note 20 .

28 United States v. Casey, supra note 21; Public Service Comm. v. New York Central R. Co., supra note 23. 